El-Dyasty, M.A., \& Elamer, A.A., (2020) 'The effect of auditor type on audit quality in emerging markets: Evidence from Egypt', International Journal of Accounting \& Information Management, Forthcoming, (Accepted 1 August 2020). https://doi.org/10.1108/IJAIM-04-2020-0060

\title{
The effect of auditor type on audit quality in emerging markets: Evidence from Egypt
}

\author{
Mohamed M. El-Dyasty \\ Professor of Accounting \\ Department of Accounting, Faculty of Commerce, Mansoura University, Mansoura, Egypt \\ Email: mdyasty@mans.edu.eg
}

\begin{abstract}
Ahmed A. Elamer
Brunel Business School, Brunel University London, Kingston Lane, Uxbridge, London, UB8 3PH UK; and

Department of Accounting, Faculty of Commerce, Mansoura University, Mansoura, Egypt

Email: ahmed.a.elamer@gmail.com
\end{abstract}




\title{
The effect of auditor type on audit quality in emerging markets: Evidence from Egypt
}

\begin{abstract}
Purpose

Although a number of studies suggest that big audit firms provide higher audit quality in strict legal environments, empirical evidence remains inconclusive. Since little is known about the effect of auditor type on audit quality in less strictly legal environments, this study aims to investigate the impact of auditor type on audit quality in the Egyptian market.

Design/methodology/approach

Data of Egyptian-listed companies during the period 2011-2018 are employed. To examine the impact of auditor type on audit quality, ordinary least square regression and robust standard errors clustered at year and industry level are used. This study employs discretionary accruals as a proxy for audit quality. Several additional analyses are conducted to assess the robustness of the main results, including alternative measures of audit quality and auditor type.

\section{Findings}

Our results show that audit firms tend to provide higher audit quality when they are affiliated with a foreign audit firm. However, Big 4 auditors do not provide higher audit quality compare to their counterparts. Additionally, the governmental agency, Accountability State Authority (ASA), that monopolize audit function in state-owned companies do not appear to be associated with higher audit quality. Lastly, local audit firms have a negative association with audit quality. This may be their strategy to secure future clients that seek low-quality audits.

Originality/value

This study adds to the rare but growing body of literature by investigating how auditor type affects audit quality in the context of less strictly legal environments. Our results are important since investors, standards-setters and regulators have growing concerns over audit quality since the Enron scandal. The findings suggest that audit quality depends on auditor type. These findings have important implications for investors, standards-setters and auditors interested in auditor oversight, audit quality and auditor choice.
\end{abstract}

Keywords: Audit quality, Big 4, Second-tier auditors, Third tier auditors, Local audit firms, Accountability State Authority

JEL Classification M42 


\section{Introduction}

Traditionally, audit firms are classified into two broad types based on size, big audit firms and non-big audit firms. A frequent debate exists between levels of audit quality delivered by audit firms. It is argued by DeAnglo (1981) that big audit firms provide higher audit quality. Since then, many studies assert that this notion is logical (e.g., Berglund et al., 2018; Dechow and Schrand, 2004; Eshleman and Guo, 2014; Geiger and Rama, 2006; Lennox, 1999). Because big audit firms possess distinguished human resources and higher technical and technological abilities, they are able to differentiate their services from other audit firms to provide higher audit quality (Sirois, 2009).

On the contrary to this long-standing notion, the collapse of a big audit firm, Arthur Andersen, provides irrefutable evidence of poor audit quality. Arthur Andersen was, until the Enron scandal, one of the five largest audit and accountancy partnerships in the world. Before its bankruptcy in 2001, Enron was one of the leading companies in the US and the world in fields of electricity, natural gas, communications, and pulp and paper. The accounting irregularities revealed at Enron and not detected by Arthur Andersen represents one of the biggest audit failures in history (Li, 2010; Nelson et al., 2008). Consequently, the financial press and the public criticize the auditing profession and question the level of audit quality provided big audit firms. Based on this criticism, the self-regulation of the auditing profession is terminated and Sarbanes-Oxley enacted. The Public Company Accounting Oversight Board (PCAOB) was established to oversee the auditing profession (Francis, 2004).

Besides what is documented in the real-world, prior research is not indicating a piece of conclusive evidence regarding audit quality provided by the big audit firms. For example, Lawrence et al. (2011) reported based on three proxies of audit quality that Big 4 audit firms are insignificantly different from non-big audit firms. Likewise, Berglund et al. (2018) conclude that empirical evidence on the association between auditor size and going concern frequency is quite mixed. It is not quite evident that mixed results were reached because of the poor performance of big audit firms or methods used in designing research. Accordingly, Fuerman (2004) assumed that the notion suggested by DeAnglo (1981) might not be completely valid and called for developing a more complex theory of audit quality. He indicates that audit quality is merely a function of auditor size and other paradigms, such as behavioral, ethical and cultural aspects, must be considered in order to understand audit quality. 
In addition, auditing literature considers a change in classifying audit firms. The traditional classification of big audit firms versus non-big audit firms is not valid to describe audit market precisely. The concept of second-tier emerged to divide non-big audit firms into additional two types of audit firms. Therefore, the Big 4 audit firms represent the top tier. The next four audit firms are placed into a new tier; second-tier. Finally, other audit firms will be placed in small firms tier. Accordingly, second-tier include BDO, Crowe Chizek and Company, Grant Thornton, and McGladrey \& Pullen (Dey and Robin, 2011; Herda et al., 2014).

Egypt has a unique and complex audit market. Egypt is one of a few countries that permits mandatory audit alongside voluntary audit (Mohamed and Habib, 2013). On the one hand, each publicly held company might choose, upon discretion, to hire one audit firm or more [Article 103 of Law 159/1981]. Only public accounting firms are considered to perform the audit in publicly held companies. Accordingly, if a company decides to appoint more than one audit firm, a joint audit is applied. Audit firms in Egypt are classified into two broad categories, firms affiliated with foreign audit firms and local audit firms. The first category involves all tiers of audit firms, including big auditors. The other category contains small firms that are not affiliated with foreign firms. What is interesting about the Egyptian market is the fact that many audit firms are seeking to distinguish themselves by affiliating with foreign audit firms. This feature may not be observed all over the world. Also, Big 4 consider as, legally, brands rather than legal entities due to the Egyptian law restrictions (Eldaly and Abdel-Kader, 2017).

On the other hand, the Egyptian market also includes state-owned companies. If the Egyptian State own at least 25 percent of a company, a statutory auditor, called Accountability State Authority (ASA), must be appointed to audit financial statements (Article of Law 144/1988). Traditionally, ASA reports are not limited to serve the external needs of financial statements users. The primary objective of these reports is to evaluate financial and managerial performance and decide the degree of conformity with laws and regulations. Therefore, ASA reports are prepared to provide detailed information to the highest governmental authorities. These reports contain a long list of remarks and recommendations. Some reports may include fifty pages or more. Normally, because ASA reports cover a wide range, most of them provide a qualified opinion that may not necessarily reflect a nonconformity with accounting principles ${ }^{1}$. Accordingly, article 4 of

\footnotetext{
${ }^{1}$ Capital Market Authority (CMA) in Egypt requires all listed companies of the Egyptian stock exchange to prepare its financial statements and audit it in accordance to the Egyptian standards. Egyptian accounting standards are
} 
Law 144/1988 allow each state-owned company to appoint an audit firm. This lead to apply dual audits. Since Philosophy and objectives differ, it is hard for any audit firm to perform a joint audit with ASA.

El-Dyasty (2017) analyzed the structure of the Egyptian audit market. The two key players are audit firms affiliate with international big 4 audit firms (\%34) and ASA (\%22). Single audits represent $\% 72$ in Egypt. Nearly \%.14 of audits are performed jointly via public accounting firms. Similarly, \%14 of state-owned companies select a dual audit by hiring public accounting firms alongside ASA. Consequently, it is hard to attribute audit quality in both joint audits and dual audits to a single audit firm. In addition, \%60 of audit firms in Egypt affiliate with foreign auditors of all tiers. Surpassingly. One-third of these firms affiliate with third-tier auditors. It is common to consider foreign names affiliated with Egyptian auditors rather than the form of the legal entity that audit firms take. Thus, the Egyptian audit market is complex. Overlapping of performance among audit firms concerning audit quality is a noticeable issue in nearly one-third of the market. Besides that, big 4 audit firms are not controlling the market. Some Investors may not be able to distinguish between levels of audit quality provided by audit firms in Egypt affiliate with foreign auditors.

Prior research explored the association between auditor type and audit quality in Egypt is somehow limited and reported mixed results (Abdallah 2018; El-Dyasty, 2017; Khalil and Ozkan, 2016; Yasser and Soliman 2018). Accordingly, this study aims to inspect the effect of auditor type on audit quality. The focus is to examine two issues in the Egyptian market. The first issue is untested earlier in audit literature. Since many audit firms in Egypt adopt a strategy to affiliate with foreign audit firms, it will be useful to understand the effect on audit quality. The second issue is to evaluate in-depth the level of audit quality under a mandatory audit performed by a governmental agency.

To achieve this objective, a sample of unconsolidated financial statements and accompanied audit reports is used. The sample covers the period from 2011 to 2018 . To isolate the

\footnotetext{
formulated based on the international financial reporting (IFRS). Similarly, The Egyptian auditing standards are based heavily on the International Auditing Standards (IAS). Normally, a member of Egyptian cabinet appoints special committees to translate and formulate IFRS and IASs in order to suit the Egyptian environment. Based on the committee's reports, the minster of investment and international cooperation issues ministerial decrees to mandate the standards.
} 
effect of joint audits and dual audits on audit quality, only single audit reports are considered. Two types of proxies of audit quality were used, abnormal accruals based on the modified-Jones model and Kothari et al. (2005) model. Our findings show that audit firms that affiliate with foreign audit firms provide higher audit quality. Second, the governmental agency, Accountability State Authority (ASA), that monopolize audit function in state-owned companies do not appear to be associated with higher audit quality. Lastly, local audit firms have a negative association with audit quality.

This study contributes to the rare but growing body of literature by investigating how auditor type affects audit quality in the context of less strictly legal environments. First, while the extant auditing research focusses on the impact of Big 4 of earnings management, our study seeks to relate other auditor types to earnings management as an inverse proxy of audit quality. That is, our study adds to the audit quality literature by offering evidence for the first time that shows that the audit firms that affiliate with foreign audit firms provide higher audit quality. Second, while most prior audit quality studies have used Big 4 as a proxy of audit quality, we extend them by using a context of less strictly legal environment (Abdelhak et al., 2019). Our results suggest that Big 4 auditors are not associated with audit quality. Third, this study setting characterized by institutional voids and generally weak legal environment offers a unique environment to explore how Egyptian audit firms' types (local auditors, governmental agency, and auditors affiliated with foreign auditors) affect audit quality. In this case, our results show that local (foreign-affiliated) audit firms have a negative (positive) association with audit quality. Finally, our results have implications for investors, standards-setters and regulators. Our results suggest that they should consider not only Big 4 as provider of high audit quality, but also other forign auditors such as second- and third-tier auditors as factors that can potentially influence audit quality.

The rest of this study is organized as follows. Section 2 provides a literature review and presents hypotheses development. Section 3 discusses the methodology and the sample. Empirical results and discussion are reported in section 4. Section 5 includes the summary and conclusion.

\section{Literature Review and Hypotheses Development}

Auditing is a cornerstone of financial reporting quality (Khlif and Souissi, 2010; Shahzad et al., 2019; BenYoussef and Drira, 2020). The main objective of financial statements audit is to reduce information risk. Financial statements are prepared by management and cannot be directly verified by any of the stakeholders, including the owners (Gerged \& Elheddad, 2020; Gerged \& 
Agwili, 2020). Accordingly, these statements contain only the management's point of view. This may cause information asymmetry (Gerged et al., 2018, 2020). Therefore, users cannot rely on financial statements. Without auditing, users may make decisions based on misleading information (Hassan et al., 2020). Thus, independent opinion is needed. The audit report is formulated to send a message form an independent and professional person to lend creditability to the financial statements. The audit report is a tool to inform users whether financial statements have been prepared in accordance with accounting principles. To ensure audit quality, the auditor must perform the audit process and formulate his opinion in accordance with auditing and quality control standards.

Unfortunately, users are not able to observe and evaluate audit quality. Consequently, proxies of audit quality were used in literature (e.g., Hammami and Zadeh, 2020; DeFond and Zhang, 2014; Jung et al., 2016). The most common proxies are abnormal accruals and accuracy of going concern opinion. These proxies are mainly employed to examine the association between auditor size type and audit quality. The objective is to understand the notion of differentiation of services provided by big audit firms compared to other audit firms in the US and other countries. For example, Geiger and Rama (2006) examined audit quality at Big 4 audit firms and non-big audit firms. They used the accuracy of going concern opinion as a proxy of audit quality. Findings indicate that Big 4 audit firms outperform non-big audit firms. No significant differences were found between audit quality provided by second-tier auditors and other audit firms. Likewise, Chia et al. (2007) reported that only big audit firms are able to constrain earnings management in Singaporean companies during the Asian financial crisis.

Sirois (2009) examined the association between auditor size and audit quality in the US audit market. Results reported that Big 4 audit firms outperform non-big audit firms. Big 4 audit firms are able to increase their share in the audit market due to innovating audit technology. Similarly, Wang and Xin (2011) investigate the association between auditor size and the accruals pattern of listed companies in Hong Kong. The results suggest that Big 4 provide higher audit quality compare to non-big 4.

Memiş and Çetenak (2012) examined the association between auditor size and audit quality in private firms across different emerging countries. Big 4 audit firms provide higher audit quality in Brazilian and Mexican companies. No significant association is found in other countries. Likewise, Mo et al. (2015) tested the association between auditor size and audit quality in China. 
They employ accuracy of going concern opinion as a proxy of audit quality. A sample is collected to compare audit quality provided by audit before and after the enactment of bankruptcy law in 2006. Litigation risk increased due to the enactment of bankruptcy law in 2006. Big 4 audit firms in China are consistently providing higher audit quality regardless of legal requirements to preserve their reputation. In contrast, local top-10 auditors increase their propensity to issue goingconcern opinions after the passage of bankruptcy law.

Comprix and Huang (2015) examined whether small audit firms are able to restrict earnings management. Small audit firms are defined as audit firms with 100 or fewer clients. Results indicate that small audit firms are less able to constrain earnings management activities. Therefore, they are not providing higher audit quality. Similarly, Houqe et al. (2017) indicate a positive association between Big 4 auditors and audit quality measured by abnormal accruals in India. Same results are found when replacing Big 4 audit firms with the top set of audit firms ranked by the number of client firms in the sample of companies and market share.

Astami et al. (2017) examined the association between audit quality and auditor size in the Asia-Pacific region. Using abnormal accruals as a measure of audit quality, the evidence indicates that Big 4 audit firms are able to provide higher audit quality. Likewise, Mokoaleli-Mokoteli and Latridis (2017) examine the association between auditor size and both of earnings management and earnings conservatism in South Africa that has an advanced regulated system. Results indicate that companies audited by Big 4 auditors are less engaging in earnings management and tend to recognize significant losses on time. Likewise, Lopes (2018) investigated the relationship between audit firms and audit quality in Portugal. Results suggest that Big 4 audit firms outperform nonbig audit firms. In addition, Berglund et al. (2018) used the accuracy of going concern opinion in distressed companies as a proxy of audit quality. Results indicate that Big 4 audit firms outperform second-tier auditors. Specifically, Big 4 are less likely to issue false-positive going concern opinions. Finally, Reguera-Alvarado et al. (2019) investigate the association between auditor size and audit quality. They use a sample of listed companies from the US, the United Kingdom, Japan, Italy, France and Spain. Results show that Big 4 audit firms provide higher audit quality than other audit firms.

Limited research in the Egyptian context investigates the association between big 4 firms and audit quality. Mixed results were reported. Khalil and Ozkan (2016) conclude that big 4 firms and ASA are providing higher audit quality compared to other audit firms. This result may not be 
conclusive. They combine big 4 firms and ASA as a unit. Therefore, it is not clear whether this result could hold for Big 4 firms or ASA separately. On the contrary, Yasser and Soliman (2018) and El-Dyasty (2017) reported an insignificant relationship between big 4 firms and audit quality. Besides, Abdallah (2018) provides a significant negative relationship between big 4 firms and audit quality. Egypt is trying to attract foreign investments. Therefore, reforming financial and oversight systems is continually progressed to achieve this goal. Egyptian government establishes financial regulatory authority to oversee the audit profession. The purpose is to supervise the capital market and monitor the quality of financial information disseminated by corporations. Accordingly, the Audit Oversight Board established to monitor the quality of audit services provided for listed companies (Eldaly and Abdel-Kader, 2017). Consequently, big 4 audit firms may be more eager to provide higher audit quality regardless of a less strict legal environment. Hence, $\mathrm{H} 1$ is formulated as follows.

\section{$H_{1}$ : Egyptian audit firms that affiliate with Big 4 provide higher audit quality.}

Prior research investigates whether audit firms other than big audit firms are able to provide similar audit quality or not. Cassell (2009) examined the association between auditor size and audit quality. Results indicate that the performance of second-tier auditors improved in the post-Arthur Anderson period. No difference is found between audit quality provided between second-tier auditors and Big 4 auditors in the post- Arthur Anderson period. In addition, second-tier auditors provide higher audit quality compared to other non-big audit firms. Likewise, Wagner (2011) investigated audit quality in second-tier auditors before and after enacting Sarbanes Oxley Act (SOX). Results indicate that audit quality provided by second-tier auditors improved after SOX. However, since Big 4 audit firms are able to constrain abnormal accruals, they still provide a higher audit quality than second-tier auditors.

In contrast, Lawrence et al. (2011) examined the differences in proxies for audit quality between Big 4 and non-big 4 audit firms. Audit quality is measured by abnormal accruals, costof-equity capital and analyst forecast accuracy. No significant difference was found between audit quality provided by Big 4 and non-big four audit firms. Cassell et al. (2013) compared the image of second-tier auditors before and after collapsing of Arthur Anderson. They found that financial reporting creditability of second-tier clients was lower than that of Big 4 clients before the 
collapsing of Arthur Andersen. On the contrary, after collapsing of Arthur Andersen, financial reporting creditability of second-tier clients cannot be distinguished from that of Big 4.

The strategy adopted by many Egyptian audit firms to affiliate with foreign audit firms may reflect their desire to benefit from foreign names to increase their share in the Egyptian market. It could also be argued that such strategy is selected to convince financial statement users to look at all affiliated audit firms, including Big 4, as one unit that provides superior audit quality compared to local audit firms. In addition, it is noticeable that foreign audit firms in the Egyptian market are not limited to Big 4 or second-tier auditors. Affiliating with foreign firms other than big auditors is common in Egypt. Little is known about audit quality provided by Egyptian audit firms that affiliate with foreign auditors. To test audit quality provided by affiliated audit firms in Egypt, the following hypotheses are formulated.

\section{$\mathrm{H}_{2}$ : Egyptian audit firms that affiliate with foreign audit firms provide higher audit quality.}

Prior research in countries other than the US reported that audit quality provided might not differ between Big 4 audit firms and non-big audit firms. For example, Bauwhede et al. (2003) compare audit quality provided by big audit firms and other audit firms in Belgium based on abnormal accruals as a proxy of audit quality. No evidence is found of audit quality provided by big auditors and other auditors in companies aimed to manage earnings to reduce income. Likewise, Jeong and Rho (2004) reported no significant difference between audit quality delivered by big audit firms and non-big audit firms in Korea based on abnormal accruals as a proxy of audit quality. Similar results were found in other countries. Hunt and Lulseged (2007) concluded that both non-big audit firms and audit firms are able to constrain earnings management. Further, both types of audit firms are likely to provide similar audit quality based on accuracy of going concern opinion as a proxy of audit quality. Likewise, Kabir et al. (2011) used abnormal accruals to measure audit quality. They found that firms affiliated with Big 4 have no effect on audit quality in Bangladesh.

Also, Sundgren and Svanström (2013) examined the association between auditor size and audit quality in Sweden. They used disciplinary sanctions issued against auditors not meeting the quality requirement as the measure of audit quality. They found no significant differences between Big 4 audit firms and two of second-tier auditors, Grant Thornton and BDO. The other auditors in the Swedish market do not provide the same audit quality. Similarly, Yaşar (2013) used a sample 
of listed companies on the Istanbul stock exchange to examine the association between auditor size and audit quality. He reported that auditor size does not affect audit quality. No difference is found between the abilities of Big 4 and non-big 4 audit firms to restrict earnings management in Turkey. Likewise, Campa (2013) used a sample of non-financial companies listed on the UK stock market. Findings show that Big 4 audit firms do not provide higher audit quality. Furthermore, the financial market does not perceive the difference in earnings disclosed by Big 4 audit firms and non-big audit firms. In addition, Khanh and Khuong (2018) found no difference between big auditors and non-big auditors in mitigating or eliminating earnings management in Vietnam.

Park (2017) investigated the association between auditor size and audit quality on a sample of listed companies of the Korean stock exchange. Findings suggest that Big 4 audit firms are not providing higher audit quality to powerful clients. Similarly, Abid et al. (2018) examined the association between auditor type and audit quality in a sample of firms listed on Karachi Stock Exchange in Pakistan. They found no significant difference between audit quality delivered by big and non-big audit firms. Likewise, Orazalin and Akhmetzhanov (2019) reported that Big 4 audit firms are not effective to deter earnings management practices of Kazakh public companies. Finally, Semba and Kato (2019) investigate levels of audit quality delivered by Japanese audit firms. No difference is found between audit quality provided by all audit firms in Japan.

Since Egypt has a unique environment, it will be useful to understand the effect of other types of audit firms on audit quality. Contrary to the US, Egypt is like most other developing countries that have less strict legal and regulatory environments. Therefore, facing litigation risk or disciplinary actions are rare. Accordingly, no pressures are expected to provide higher audit quality by Big 4 auditors. Hence, the following hypothesis will be tested.

\section{$H_{3}$ : Big 4 and Local audit firms in Egypt provide similar level of audit quality}

Prior research reported mixed result concerning the level audit quality provided by ASA. Both Abdallah (2018) and El-Dyasty (2017) show no association between ASA and audit quality. However, Khalil and Ozkan (2016) pointed out that big 4 and ASA as a unit are providing higher audit quality compared to other accounting firms in the Egyptian market.

ASA's auditors are appointed by law to audit financial statements prepared by companies owned fully or partly by the Egyptian state. If Egyptian state-owned $25 \%$ or more of equity, the company's financial statements must be audited by ASA. Therefore, ASA is performing a 
mandatory audit. Since ASA is a governmental agency, the employed auditors represent the Egyptian state and they are part of governmental officials. Their independence is guaranteed. Contrary to audit firms. ASA's auditors have a formal status that enables them to provide remarks and recommendations. The audited companies must respond officially to these remarks and recommendations. Egyptian companies cannot change or fire ASA's auditors. These auditors do not fear the consequence of their opinion. Consequently, ASA's auditors have a unique position to provide higher audit quality compared to audit firms. Hence, the following hypothesis will be tested:

\section{$H_{4}:$ ASA provides higher audit quality}

\section{Research design}

\subsection{Sample selection and data sources}

A sample of unconsolidated financial statements for non-financial companies listed in Egyptian stock exchange (EGX) is used to test the research hypotheses. The sample covers the period between 2011 and 2018. The sampling period starts in 2011 to avoid the 2007/2008 financial crisis and 2010 turmoil (Alnabsha et al., 2018). This design provides us to get sensible panel data with the benefits of developing the degrees of freedom and decreasing the likelihood of multicollinearity among the examined variables (Wooldridge, 2010). This design also offers us the chance to compare the present results with the findings of earlier studies (Alnabsha et al., 2018; Reguera-Alvarado et al., 2019).

In order to investigate the impact of auditor type on audit quality, the firm-level variables and auditor characteristics were hand-collected from the sampled firms' annual reports, their websites, and capital markets' websites. Specifically, data were obtained from the companies' websites and a financial website (i.e., Mubasher). Only official pdf versions of financial statements were considered. Since this study aims to investigate the association between auditor type and audit quality, only data that relate to single audits are used. Audit type other than single audits may not be useful for this study. Cooperation and allocation of work between participating auditors are essential to perform joint audits. Therefore, it is hard to evaluate audit quality provided by each audit firm. Likewise, dual audits represent a particular case of audit. Each audit firm engages in 
dual audit must be alert of the existence of ASA. Accordingly, audit firms who perform dual audit may reduce audit risk to avoid discrepancies with the content of ASA's reports ${ }^{2}$.

Consequently, the behaviour of the audit firm in a dual audit may not reflect the usual audit quality. Thus, isolating joint and dual audits will reduce the observations from 1333 to 950 . In addition, to apply abnormal accruals through a modified-Jones model, some terms must be met. For each industry, at least ten observations must be used. Some sectors classified by the Egyptian stock exchange contain one company. Other sectors include less than ten companies. Heterogonous industries are included in some sectors. Only five sectors of the fifteen sectors specified by the Egyptian stock exchange could be used to apply the modified-Jones model. In this case, 602 observation could be used.

\subsection{Measurement of variables and model specification}

In our empirical investigation, we use three main categories of variables. First, audit quality is our primary dependent variable. Second, our main independent variable is auditor type. Lastly, based on literature (e.g., Abid et al., 2018; Kabir et al., 2017; Lawrence et al., 2011; Yaşar, 2013), this study includes a number of control variables. Table 1 defines all variables employed in this research.

\subsubsection{Auditor quality}

The absolute value of discretionary accruals has been employed as a proxy for earnings management (dependent variable). Most prior literature has used a cross-sectional regression of the cross-sectional modified Jones (1991) model because prior research finds this model to be superior in identifying abnormal accruals (e.g., Dechow et al., 1995; Jaggi and Leung, 2007; Yasser and Soliman 2018; El-Dyasty, 2017; Khalil and Ozkan, 2016). We need at least 10 firms per industry-year to estimate this variable. To estimate abnormal accruals (consistent with DeFond and Jiambalvo (1994) and Subramanyam (1996)), we calculate the residuals in the modified Jones (1991) model as follows.

\footnotetext{
2 To understand the effects of joint audits and dual audit on audit quality, reader may refer to Mandour et al. (2018); El-Dyasty (2017); El Assy (2015)
} 


$$
\frac{T A_{t}}{A_{t-1}}=\alpha_{0}+\beta_{1} \frac{1}{A_{t-1}}+\beta_{2} \frac{\left(\Delta R E V_{t}-\Delta R E C_{t}\right)}{A_{t-1}}+\beta_{3} \frac{P P E_{t}}{A_{t-1}}+\varepsilon_{t}
$$

where,

TA refers to total accruals; $\mathrm{A}_{\mathrm{t}-1}$ refers to total assets at the end of year $t-1 ; \Delta \mathrm{REV}_{\mathrm{t}}$ refers to revenues in year $t$ less revenue in year $t-1 ; \Delta \mathrm{REC}_{\mathrm{t}}$ refers to net receivables in year $t$ less net receivable in year $t_{-1}$; $\mathrm{PPE}_{\mathrm{t}}$ refers to gross property plant and equipment at the end of year $t$. For robustness, we also employ the empirical analysis using the cross-sectional modified Jones (1991) model, augmented with return on assets as suggested by Kothari et al. (2005), estimated by industry-year in an additional analysis and represent the findings of these analyses in a separate section.

\subsubsection{Auditor type}

Our main independent variable is auditor type, represented by four sub-variables. Following earlier research, our first proxy of auditor type is Egyptian audit firms that affiliate with Big 4 audit firms $(B I G)$, which is a dummy variable equals1 if the firm i audited by a Big 4 audit firm, and 0 otherwise. The second proxy of auditor type is Egyptian audit firms that affiliate with foreign audit firms (Foreign), which is a dummy variable equals1 if the firm i audited by Egyptian audit firms that affiliate with a foreign audit firm, and 0 otherwise. The third proxy of auditor type is Egyptian local audit firms (Local), which is a dummy variable equals1 if the firm i audited by a local audit firm and 0 otherwise. The last proxy of auditor type is the Accountability State Authority $(A S A)$, which is a dummy variable equals1 if the firm i audited by the Accountability State Authority, and 0 otherwise.

\subsubsection{Control variables}

Consistent with prior literature (e.g., Abid et al., 2018; Kabir et al., 2017; Lawrence et al., 2011; Yaşar, 2013), the current study controls for possible omitted variables bias by incorporating a number of control variables that have been discovered to have an influence on audit quality, namely financial stress score (ZIM), leverage (Leverage), profitability (ROA ), firm loss (Loss), firm size (FSIZE), inherent risk (Inherent), operating-cash-flow-to-total-assets ratio (OFLow), firm age (LnAge), firm complexity (Complex), year fixed effects (Year_FE), and industry fixed effects (Industry_FE).

\subsection{Model specification}


This study develops an OLS regression model to test the impact of auditor type on audit quality for 602 firm-year observations during the period 2011 to 2018. Model 2 specification is of the following general form to test research hypotheses (e.g., Abid et al., 2018; Kabir et al., 2017; Yaşar, 2013).

Audit quality it $=\beta_{0}+\beta_{1}$ Auditor $_{i t}+\beta_{2}$ ZIM $_{i t}+\beta_{3}$ Leverage $_{i t}+\beta_{4}$ Loss $_{i t}+B_{5}$ ROA $+B_{6}$ FSIZE $_{i t}+B_{7}$ Inherent $_{i t}+B_{8}$ OFLow $_{i t}+B_{9}$ LnAge $_{i t}+\beta_{10}$ Complex $_{i t}+$ Industry_FE $_{-}$Year_FE + $\varepsilon_{i t}$

where,

Audit quality refers to the absolute value of discretionary accruals as a proxy of audit quality for firm $i$ during year $t$; Auditor refers to auditor type; ZIM denotes financial stress score, Loss denotes firm loss, ROA denotes profitability, Leverage denotes leverage, Losss denotes firm loss, FSIZE denotes firm size, Inherent denotes inherent risk, OFLow denotes operating-cashflow-to-total-assets ratio, LnAge denotes firm age, Complex denotes firm complexity, Year_FE denotes year fixed effects, and Industry_FE denotes industry fixed effects. Table 1 shows the definition of variables.

\section{$\underline{\text { Insert Table } 1 \text { about here }}$}

\section{Empirical results and discussion}

\subsection{Descriptive statistics and bivariate analyses}

Table 2 displays descriptive statistics for variables. The absolute values of discretionary accruals $\mid$ ABACC | have a mean value of 0.08 . Big 4 control $22 \%$ of single audits of the Egyptian market of listed companies according to our sample. Remarkably, audit firms that affiliate with foreign audit firms dominate about 52\% of the audit market in Egypt. Second-tier audit firms audit only $5 \%$. In contrast, audit firms affiliate with third-tier auditors control $25 \%$ of the Egyptian market. Hence, many audit firms in Egypt think that using foreign names of audit firms will enhance their image in the Egyptian market. If only 4 big audit firms are available, affiliation with other foreign firms will provide much help to gain a respectful reputation. On the contrary, local audit firms in Egypt still control significant share. Nearly one-third of Egyptian companies appoint local audit firms. ASA performs mandatory audits. Nearly $15 \%$ of single audits are provided for state-owned companies. 


\section{Insert Table 2 about here}

The correlation matrix is displayed in Table 3. Table 3 indicates correlations based on 602 observations and displays the associations between $|\mathrm{ABACC}|$ and other variables. All types of audit firms have an insignificant association with $|\mathrm{ABACC}|$ except audit firms that affiliate with foreign audit firms.

Further, Table 3 shows that only four variables have a significant association with |ABACC $\mid$. Only the financial stress score, leverage, ROA and OFLEW have a positive association with $|\mathrm{ABACC}|$. However, these findings are preliminary and interpretations should only be complete after the presence of other control variables in the regression model. The correlation matrix generally does not donate any severe potential multicollinearity problems.

\section{Insert Table 3 about here}

\subsection{Multivariate regression results and discussion}

Table 4 represents the regression results. In Model 1 of Table 4, we test our H1: whether Egyptian audit firms that affiliate with Big 4 provide higher audit quality using OLS and robust standard errors clustered at year and industry level (Petersen, 2009). The coefficients of Big 4 (Big) in Model 1 of Table $4(\mathrm{Coef}=-0.003)$ is negative but insignificant statistically, implying that Egyptian audit firms that affiliate with Big 4 do not provide higher audit quality. This implies that Big 4 do not mitigate earnings management. The insignificant connection between Big and ABACC (audit quality) is in line with theoretical suggestions that less strict legal environment discourages audit firms from providing higher audit quality. Likewise, the absence of a professional body to formulate accounting and auditing standards may negatively affect the level of audit quality provided by Egyptian audit firms. Our findings do not support $\boldsymbol{H}_{\boldsymbol{1}}$. However, our results support previous findings (Campa, 2013; Khanh and Khuong, 2018; Park, 2017; Sundgren and Svanström, 2013; Yaşar, 2013), which suggest that Big 4 auditors do not provide higher audit quality.

Comparing the outcome of testing H1 in the current study with prior studies in the Egyptian context indicates that Big 4 firms are not providing a higher audit quality. Both Abdallah (2018) and El-Dyasty (2017) reported the same conclusions. However, Khalil and Ozkan (2016) show contradictory results. Their conclusion cannot be confirmed due to employing Big 4 alongside ASA in one variable. Therefore, their results cannot be attributable to any of Big 4 or ASA alone. 


\section{Insert Table 4 about here}

We then investigate whether auditors affiliate with foreign audit firms as a unit provide higher audit quality or not. This phenomenon may reflect the desire of Egyptian auditors to gain a better reputation. If only four Egyptian audit firms could benefit from affiliating with Big 4 auditors, the idea of having a foreign name seems reasonable. It conveys a message of the abilities of the affiliated audit firms to deliver the same or parallel audit quality provided by Big 4. Model 2 of Table 4 presents the results of testing this notion, as suggested by $\boldsymbol{H}_{2}$. Model 2 of Table 4 shows that $\boldsymbol{H}_{2}$ is empirically supported at $5 \%$ level. Auditors that affiliate with foreign audit firms provide higher audit quality by mitigating earnings management. Using foreign names of audit firms is a common phenomenon in Egypt. Nearly half of Egyptian audit firms decide to affiliate with foreign audit firms in all tiers. It is evident that many audit firms think that using foreign names is the best way to differentiate themselves in the Egyptian market. Our evidence suggests that the audit firm affiliates with a foreign audit firm is interested in increasing audit quality by alleviating earnings management. This evidence implies that affiliation with foreign auditors may help the Egyptian audit firms to develop their abilities by using advanced technology and techniques and transfer rare expertise to the Egyptian auditors. Our empirical results are consistent with the findings of some previous studies (Cassell et al., 2013; Wagner, 2011).

Model 4 of Table 8 presents the results of OLS regression to test $\boldsymbol{H}_{3}$. The results indicate that local audit firms in the Egyptian market provide poor audit quality. Under the discretionary accruals model, a positive (negative) significant association is found between local audit firms and audit quality (earnings management). This result is consistent with other past evidence that suggests that local audit firms offer less audit quality (Abdallah, 2018; El-Dyasty, 2017; Cassell, 2009; Cassell et al., 2013; Wagner, 2011). To some extent, this result implies that local audit firms in the Egyptian market are more likely to deal with less healthy client (e.g. small client).

The findings, presented in Model 3 of Table 4, show a positive but insignificant relationship between ASA and audit quality. H4 suggests that ASA in the Egyptian market provides higher audit quality. Model 3 of Table 4 displays the results of OLS regression. The results show that there is no significant association between ASA and discretionary accruals. Hence, $\boldsymbol{H}_{\boldsymbol{4}}$ is not supported. These results imply that after controlling for several client characteristics that are likely to influence discretionary accruals, ASA in the Egyptian market does not affect audit quality. This result is consistent with findings reported with Abdallah (2018) El- 
Dyasty (2017). This result may expand another strand of research (Alshbili et al., 2019; Elamer et al., 2018; Feng et al., 2020). Specifically, future research may explore the association among different auditor types and corporate social responsibility disclosures, risk-taking and capital structure

\subsection{Additional analysis}

This section extends our analysis of the impact of auditor type and audit quality in the Egyptian context and checks the robustness of the regression models and our empirical results. Our analysis proposes, so far, that audit quality is higher when audits are done by auditor's affiliate with foreign audit firms. We have, thus far, considered auditors affiliate with foreign audit firms as a homogeneous group. However, previous research (Boone et al., 2010; Cassell et al., 2013; Wagner, 2011) suggests that auditor's affiliation can be divided to three groups (Big 4, second-tier auditors ${ }^{3}$, and Third-tier auditors), which may lead to different audit quality.

Prior studies (Boone et al., 2010; Cassell et al., 2013; Wagner, 2011) reported mixed results concerning similarities (differences) of audit quality provided by Big 4 auditors and second-tier auditors. The evolution of the second-tier auditors reflects opposing ideas. On the one hand, it may provide evidence to indicate the emergence of a new tier that is able to deliver higher audit quality. On the other hand, it may indicate that client characteristics play an important role in appointing audit firms. Big audit firms do not welcome risky clients. Therefore, these clients will prefer to seek other audit firms. Consequently, the superiority of audit quality provided by Big 4 auditors might heavily depend on the client that they are dealing with. Thus, expanding the market share of second-tier auditors may not be considered as evidence of providing higher audit quality. Instead, this may indicate a willingness to accepting more risky clients that Big 4 rejected. If this notion is true, the significant difference will continue between audit quality provided by both big auditors and second-tier auditors. By accepting healthy clients, Big 4 auditors are only focusing on audit quality, while the second-tier auditor is concentering on expanding their market share. Accordingly, Big 4 are interested in preserving their reputation in the SOX era, while second-tier auditors are interested in establishing a new image to differentiate themselves in the audit market.

\footnotetext{
${ }^{3}$ The second-tier auditor are identified based on the study of Dey and Robin (2011) and Herda et al. (2014) and not based on the market share of foreign audit firms in the local market in the time of the study.
} 
In order to investigate this conjecture, we reran our regression model to examine whether auditors affiliate with second, third-tier or a foreign audit firm other than Big 4. The results are reported in Models 5, 6 and 7 of Table 4. Model 7 of Table 4 shows that the coefficient for auditors affiliate with third-tier audit firms is negative and significant at the 5\% level, suggesting that the auditors who affiliate with third-tier audit firms are likely to engage in high audit quality by restraining abnormal accruals. Similarly, Model 5 of Table 4 suggests that there is a significant relationship between the Egyptian audit firms that affiliate with a foreign audit firm other than Big 4 and audit quality at the 5\% level. On the other hand, Egyptian audit firms that affiliate with second-tier auditors are not playing a positive role in the Egyptian audit market. Model 6 of Table 4 suggests that no association is found between second-tier auditors and audit quality in other companies.

Additionally, we repeat our examination using an alternative measure of audit quality, namely the Kothari et al. (2005) model, augmented with return on assets, given the limitations of the original Jones model (see Kothari et al., 2005) as follows.

$$
\frac{T A_{t}}{A_{t-1}}=\alpha_{0}+\beta_{1} \frac{1}{A_{t-1}}+\beta_{2} \frac{\left(\Delta R E V_{t}-\Delta R E C_{t}\right)}{A_{t-1}}+\beta_{3} \frac{P P E_{t}}{A_{t-1}}+\beta_{4} R O A_{t}+\varepsilon_{t}
$$

Table 5 reports the results of estimating the Kothari et al. (2005) model. The results suggest inferences that are similar to those in our main findings. Specifically, there was no significant difference in the audit quality when we employ the Kothari et al. (2005) model compared to the modified Jones (1991) model.

\section{Insert Table 5 about here}

Lastly, to address potential endogeneity problems that may be due to omitted variables (Elamer et al., 2019a, b, 2020), we use fixed effects regression technique. We employed the fixed effects model instead of the random effects model because Hausman's specification test rejected random effects in favour of fixed effects. Therefore, we re-estimate equation (2) as specified below:

Audit quality it $=\beta_{0}+\beta_{1}$ Auditor $_{i t}+\beta_{2}$ ZIM $_{i t}+\beta_{3}$ Leverage $_{i t}+\beta_{4}$ Loss $_{i t}+B_{5}$ ROA $+B_{6}$ FSIZE $_{i t}+B_{7}$ Inherent $_{i t}+B_{8}$ OFLow $_{i t}+B_{9}$ LnAge $_{i t}+\beta_{10}$ Complex $_{i t}+\delta_{i t}+\varepsilon_{i t}$ 
where, everything remains unaffected as identified in equation (2) except that we use firm-year specific fixed effect $(\delta)$. The results, reported in Models 1 to 7 of Table 6 are similar to those reported in Models 1 to 7 in Table 4, and thus suggest that our findings do not suffer from any potential endogeneity problems.

\section{Insert Table 6 about here}

\section{Summary and conclusion}

Legislations and regulations may affect the level of audit quality that audit firms could deliver. In a strict legal environment, such as the US, audit firms may exert a significant effort to increase audit quality to avoid litigation (Khurana and Raman, 2004). It was evident that less strictly legal environments may cause audit firms to pay little attention to the audit quality (Semba and Kato, 2019). No difference is found between Big 4 audit firms and other audit firms in such environments (Abid et al., 2018).

The objective of this study is to examine the effect of auditor type on audit quality in Egypt. Since Egypt has a unique and complex environment, it will be interesting to investigate the association between auditor type and audit quality. Many audit firms in Egypt prefer to affiliate with foreign audit firms. Therefore, besides affiliating with the Big 4 audit firms, many of the Egyptian audit firms affiliate with auditors in second and third tires. The research hypotheses were formulated to examine the effect of each auditor type on audit quality. We investigate this issue using a sample of non-financial listed Egyptian companies over the years 2011-2018. Two proxies of audit quality were employed, which are abnormal accruals based on the modified-Jones model and Kothari model.

Our results show that Egyptian audit firms that affiliate with foreign audit firms, in general, are positively affecting audit quality. Likewise, Egyptian audit firms that affiliate with third-tier auditors tend to provide a higher audit quality. On the other hand, Egyptian audit firms that affiliate with Big 4 or second-tier auditors are not playing a positive role in mitigating earnings management in the Egyptian market. Our results suggest that if the audit firm affiliates with a foreign audit firm, especially third-tier auditors, the outcome may reflect that the firm is interested 
in increasing audit quality. Finally, our results suggest that local auditors and the government agency (ASA) that is engaged to audit listed state-owned companies on a mandatory basis in Egypt provide poor audit quality.

This study contributes to the existing literature in three main ways. First, this study offers new evidence on the extent to which auditor type influence audit quality. Second, we provide new evidence on the effect of the government agency (ASA) that is engaged to audit listed state-owned companies on a mandatory basis in Egypt on audit quality. Lastly, using a unique (hand collected) dataset in a less strictly legal environment helps us shed further light on the audit quality of different auditors in a developing country.

There are several important implications of our study. First, this study suggests that affiliation with foreign audit firms will help the Egyptian firms to develop their abilities by using advanced technology and techniques and transfer rare expertise to the Egyptian auditors. On the contrary, our results show that affiliation with Big 4 and second-tier auditors is not associated with audit quality. The strategy adopted by many Egyptian audit firms to affiliate with foreign auditors reflects the desire of these firms to be included in one tier alongside Big 4 audit firms to increase their market share under a claim of providing a higher audit quality. The results of this study indicate that this strategy may accomplish success. However, the in-depth analysis indicates that not all audit firms affiliated with foreign auditors can be looked at as one unit. The noticeable difference is found between Big 4 auditors, second-tier, and third-tier auditors.

Second, based on results reported in this study and preceding discussion, reform is needed. A professional body to formulate accounting and auditing standards must be established. Of course, it will be useful to create an official mechanism by such a body to investigate audit quality provided by all types of audit firms. The policy adopted to affiliate with foreign audit firms must be reviewed. Encouraging the merger of Egyptian audit firms may lead to an increase in their abilities to deliver higher audit quality. Third, after abolishing socialism and making significant movements toward a free economy, it will be vital to consider changing the philosophy of ASA. Users of listed state-owned companies are not limited to governmental authorities. Other users may need different approaches when conducting the audits and different formation of audit reports. It may be time for ending monopolism in auditing state-owned companies. Of course, permitting audit firms to perform audit function in state-owned companies may enhance the competition and 
increase audit quality. Finally, the application of quality inspection programs to audits of ASA will enhance audit quality.

Finally, whereas our findings are relevant and robust, the current study is subject to a number of caveats. First, the sample is limited to 602 firm-year observations from Egypt. Future research may employ a large sample in different countries to test these relations. It is important to note that auditors that affiliate with second-tier audit firms have a limited share in the Egyptian market, which may affect our results. Second, future studies may attempt to expand our results by controlling for other factors that may affect audit quality. Third, although our audit quality proxies are employed heavily in previous research, in the future, scholars may expand their analysis by using alternative audit quality proxies (e.g., going concern decision, earnings quality). Finally, the current study conducts only quantitative analysis in investigating the impact of auditor type on audit quality in Egypt. Future research may offer new insights by conducting in-depth qualitative analysis about these questions. 


\section{References}

Abdallah, S. 2018. External auditor type, discretionary accruals and investors' reactions. Journal of Accounting in Emerging Economies. 8(3): 352-368. DOI 10.1108/JAEE-10-2017-0098

Abid, A., M. Shaique and M. Anwar ul Haq. (2018). Do Big Four Auditors Always Provide Higher Audit Quality? Evidence from Pakistan. International Journal of Financial Studies. 6(58): 1-22.

Abdelhak, E.E., Elamer, A.A., AlHares, A. and McLaughlin, C. (2019), "Auditors' ethical reasoning in developing countries: the case of Egypt", International Journal of Ethics and Systems, 35(4), pp. 558-583.

Alnabsha, A., Abdou, H. A., Ntim, C. G., \& Elamer, A. A. (2018). Corporate boards, ownership structures and corporate disclosures: Evidence from a developing country. Journal of Applied Accounting Research, 19(1), 2041.

Alshbili, I., Elamer, A.A. and Beddewela, E. (2019), "Ownership types, corporate governance and corporate social responsibility disclosures: Empirical evidence from a developing country", Accounting Research Journal, 33 (1), pp. 148-166.

Alvarado, N. R., De Fuentes, P., \& Laffarga, J. (2019). Do auditors mitigate earnings management during economic crisis?. Revista de Contabilidad-Spanish Accounting Review, 22(1), 6-20.

Astami, A., R. Rusmin, B. Hartadi, and J. Evans. (2017). The Role of Audit quality and Culture Influence on Earnings Management in Companies with Excessive Free Cash Flow: Evidence from the Asia-Pacific region. International Journal of Accounting \& Information Management. 25(1): 21-42.

Bauwhede, H., M. Willekens and A. Gaeremynck. (2003). Audit firm size, public ownership, and firms' discretionary accruals management. The International Journal of Accounting. 38:1-22.

BenYoussef, N. and Drira, M. 2020. Auditor monitoring and restatement dark period. International Journal of Accounting \& Information Management. 28 (1): 73-95. DOI 10.1108/IJAIM-07-2018-0079

Berglund, N., J. Eshleman, and P. Guo. (2018). Auditor size and going concern reporting. Auditing: A Journal of Practice \& Theory. 37(2):1-25.

Boone, J. I. Khurana, and K. Raman. (2010). Do the Big 4 and the second-tier firms provide audits of similar quality? Journal of Accounting and Public Policy.29: 330-352.

Campa, D. (2013). "Big 4 fee premium" and audit quality: Latest evidence from UK listed companies, Managerial Auditing Journal. 28(8):680-707.

Cassell, C. (2009). A new era for the Big 8? Evidence on the association between earnings quality and audit firm type. Ph.D, Dissertation, Texas A\&M University.

Cassell, C., G. Giroux, L. Myers, and Omer. T. (2013). The emergence of second-tier auditors in the US: Evidence from investor perceptions of financial reporting credibility. Journal of Business Finance \& Accounting, 40(3) \& (4), 350-372.

Chia, Y., I. Lapsley, and H. Lee. (2007). Choice of auditors and earnings management during the Asian financial Crisis. Managerial Auditing Journal. 22(2): 177- 196. 
Comprix, J., H. Huang. (2015). Does auditor size matter? Evidence from small audit firms. Advances in Accounting, incorporating Advances in International Accounting. 31: 11-20.

DeAngelo, L. (1981). Auditor Size and Audit Quality. Journal of Accounting and Economics. 3 (3): 183-199.

Dechow, D. and Schrand, C. Earnings Quality. (2004). The Research Foundation of CFA Institute. 77

Dechow, P., R. Sloan, A. Sweeney. (1995). Detecting earnings management. The Accounting Review. 70(2): 193-225

DeFond, M. and Zhang, J. 2014 A review of archival auditing research. Journal of Accounting and Economics. 58: 275-326. http://dx.doi.org/10.1016/j.jacceco.2014.09.002

DeFond, M. L., \& Jiambalvo, J. (1994). Debt covenant violation and manipulation of accruals. Journal of Accounting and Economics, 17(1-2), 145-176.

Dey, R., and A. Robin. (2011). Second-Tier Auditing Firms: Developments and Prospects. CPA Journal. [June] : $32-$ 39.

Egyptian Parliament. Law No.144/1988. Companies Law. Egypt.

Egyptian Parliament. Law No.159/1981. Companies Law. Egypt.

Elamer, A.A., AlHares, A., Ntim, C.G. and Benyazid, I. (2018), "The corporate governance-risk-taking nexus: evidence from insurance companies", International Journal of Ethics and Systems, 34(4), pp. 493-509.

Elamer, A. A., Ntim, C. G., \& Abdou, H. A. (2020). Islamic governance, national governance, and bank risk management and disclosure in MENA countries. Business \& Society, 59(5), 914-955.

Elamer, A. A., Ntim, C. G., Abdou, H. A., \& Pyke, C. (2019a). Sharia supervisory boards, governance structures and operational risk disclosures: Evidence from Islamic banks in MENA countries. Global Finance Journal, 100488.

Elamer, A., Ntim, CG., Abdou, HA., Zalata, A. and Elmagrhi, M. (2019b). The impact of multi-layer governance on bank risk disclosure in emerging markets: The case of Middle East and North Africa. Accounting Forum, 43 (2), $246-281$.

El Assy .2015. Effect of joint audit on audit quality: Empirical evidence from companies listed on the Egyptian stock exchange. International Journal of Accounting and Financial Reporting, 5(2), 195-207. DOI: 10.5296/ijafr.v5i2.8431

Eldaly, M. and Abdel-Kader, M. 2017. An independent audit oversight system in a non-developed market: the case of Egypt. International Journal of Accounting, Auditing and Performance Evaluation. 13(3): 254-279. http://dx.doi.org/10.1504/IJAAPE.2017.10005538

El-Dyasty, Mohamed M., Audit Market in Egypt: An Empirical Analysis. 2017. Available at SSRN: http://dx.doi.org/10.2139/ssrn.3002783

Eshleman, J., and P. Guo. (2014). Do Big 4 Auditors Provide Higher Audit Quality after Controlling for the Endogenous Choice of Auditor? Auditing: A Journal of Practice \& Theory. 33(4), 197-219.

Feng, Y., Hassan, A., \& Elamer, A.A., (2020) 'Corporate governance, ownership structure and capital structure: Evidence from Chinese real estate listed companies', International Journal of Accounting \& Information Management, Forthcoming. https://doi.org/10.1108/IJAIM-04-2020-0042 
Francis, J. (2004). What do we know about audit quality? British Accounting Review. 36: 345-368.

Fuerman, R. (2004). Audit quality examined one Large CPA firm at Time: Mid-1990's Empirical Evidence of Precursor of Arthur Andersen's Collapse. Corporate Ownership \& Control. 2(1): 137-148.

Geiger, M. and D. Rama. (2006). Audit firm size and going-concern reporting accuracy. Accounting Horizons. 20 (1): $1-17$.

Gerged, A. M., \& Agwili, A. (2020). How corporate governance affect firm value and profitability? Evidence from Saudi financial and non-financial listed firms. International Journal of Business Governance and Ethics, $14(2), 144-165$.

Gerged, A. M., Cowton, C. J., \& Beddewela, E. S. (2018). Towards Sustainable Development in the Arab Middle East and North Africa Region: A Longitudinal Analysis of Environmental Disclosure in Corporate Annual Reports. Business Strategy and the Environment, 27(4), 572-587.

Gerged, A., \& Elheddad, M. (2020). How can national governance affect education quality in Western Europe? International Journal of Sustainability in Higher Education. https://doi.org/10.1108/IJSHE-10-2019-0314

Gerged, A.M., Al-Haddad, L.M. and Al-Hajri, M.O. (2020), "Is earnings management associated with corporate environmental disclosure? Evidence from Kuwaiti listed firms", Accounting Research Journal, 33 (1), pp. 167-185.

Hammami, A. and Hendijani Zadeh, M. 2020, Audit quality, media coverage, environmental, social, and governance disclosure and firm investment efficiency: Evidence from Canada. International Journal of Accounting \& Information Management. 28(1): 45-72. DOI 10.1108/IJAIM-03-2019-0041

Hassan, A., Elamer, A.A., Fletcher, M. and Sobhan, N. (2020), "Voluntary assurance of sustainability reporting: evidence from an emerging economy", Accounting Research Journal, 33(2), pp. 391-410.

Herda, D., Notbohm M., and Dowdell, T. 2014. The effect of external audits of internal control over financial reporting on financial reporting for clients of Big 4, Second-tier, and small audit firms. Research in Accounting Regulation. 26(1):98-103. http://dx.doi.org/10.1016/j.racreg.2014.02.010

Houqe, M., K. Ahmed and T. Zijl. (2017). Audit quality, earnings management, and cost of equity capital: Evidence from India. International Journal of Auditing. 21: 177-189.

Hunt, A. and A. Lulseged. (2007). Client importance and non-Big 5 auditors' reporting decisions. Journal of Accounting and Public Policy. 26: 212-248.

Jeong, S. and J. Rho. (2004). Big six auditors and audit quality: The Korean evidence. The International Journal of Accounting. 39: 175-196.

Jung, S.J., Kim, B.J. and Chung, J.R. 2016. The association between abnormal audit fees and audit quality after IFRS adoption: evidence from Korea. International Journal of Accounting and Information Management. 24(3): 252-271. DOI 10.1108/IJAIM-072015-0044

Kabir, M., D. Sharma, M. Islam, and A. Salat. (2011). Big 4 auditor affiliation and accruals quality in Bangladesh. Managerial Auditing Journal. 26(2): 161-181. 
Khlif, H. and Souissi, M. 2010. The determinants of corporate disclosure: a meta-analysis. International Journal of Accounting and Information Management. 18(3): 198-219. DOI $10.1108 / 18347641011068965$

Khalil, M. and Ozkan, O. 2016. Board Independence, Audit Quality and Earnings Management: Evidence from Egypt. Journal of Emerging Market Finance. 15(1) :84-118. DOI: 10.1177/0972652715623701

Khanh, H. and N. Khuong. (2018). Audit Quality, Firm Characteristics and Real Earnings Management: The Case of Listed Vietnamese Firms. International Journal of Economics and Financial Issues. 8(4): 243-249.

Kothari, S., A. Leone, and C. Wesley. (2005). Performance matched discretionary accruals. Journal of Accounting and Economics. 39(1): 163-197.

Krishnan, G. and G. Visvanathan. (2008). Was Arthur Andersen different? Further evidence on earnings management by clients of Arthur Andersen. International Journal of Disclosure and Governance. 5(1): 36-47.

Lawrence, A., M. Minutti-Meza, and P. Zhang. (2011). Can Big 4 versus Non-Big 4 differences in audit-quality proxies be attributed to client characteristics? The Accounting Review: 86(1): 259-286.

Lennox, C. (1999). Are large auditors more accurate than small auditors? Accounting and Business Research, 29(3): $217-228$.

Li, Y. (2010). The case analysis of the scandal of Enron. International Journal of Business and Management. 5(10): $37-41$.

Lopes, A. (2018). Audit quality and earnings management: Evidence from Portugal. Athens Journal of Business \& Economics. 4(2):179-192.

Memiş, M. and E. Çetenak. (2012). Earnings management, audit quality and legal environment: An international comparison. International Journal of Economics and Financial Issues. 2(4): 460-469.

Mo, P., O. Rui and X. Wu. (2015). Auditors' going concern reporting in the pre- and post-bankruptcy law eras: Chinese affiliates of Big 4 versus local auditors. The International Journal of Accounting. 50: 1-30.

Mandour, M., Elharidy, E., and Mokhtar, E.2018. Examining the Effect of Joint and Dual Audits on Earnings Management Practices. International Journal of Accounting and Financial Reporting. 8(1): 84-114. doi:10.5296/ijafr.v8i1.12526

Mohamed, D. and Habib, M. 2013. Auditor independence, audit quality and the mandatory auditor rotation in Egypt. Education, Business and Society: Contemporary Middle Eastern Issues. 6 (2): 116-144. DOI 10.1108/EBS-072012-0035

Mokoaleli-Mokoteli, T. and G. Latridis. (2017). Big 4 auditing companies, earnings manipulation and earnings conservatism: evidence from an emerging market. Investment Management and Financial Innovations. 14(1): $35-45$.

Nelson, K., R. Price, and R. Rountree. (2008). The market reaction to Arthur Andersen's role in the Enron scandal: Loss of reputation or confounding effects? Journal of Accounting and Economics. 46: 279-293.

Orazalin, N. and R. Akhmetzhanov. (2019). Earnings management, audit quality, and cost of debt: Evidence from a central Asian economy. Managerial Auditing Journal. 34(6): 696-721. 
Park, S. (2017). Audit quality and accrual quality: Do Big 4 auditors indeed enhance accrual quality of 'powerful' clients? The Journal of Applied Business Research. 33(2):343-350.

Petersen, M. A. (2009). Estimating standard errors in finance panel data sets: Comparing approaches. The Review of Financial Studies, 22(1), 435-480.

Shahzad, F., Rehman, I., Hanif, W., Asim, G. and Baig, M. 2019. The influence of financial reporting quality and audit quality on investment efficiency: Evidence from Pakistan. International Journal of Accounting \& Information Management. 27(4): 600-614. DOI 10.1108/IJAIM-08-2018-0097

Semba, H., and R. Kato. (2019). Does Big N matter for audit quality? Evidence from Japan. Asian Review of Accounting. 27(1): 1321-7348.

Sirois, L. (2009). Auditor Size and Audit Quality Revisited: The role of market size and legal environment. Unpublished Ph. D. Dissertation. University of British Columbia.

Subramanyam, K. R. (1996). The pricing of discretionary accruals. Journal of Accounting and Economics, 22(1-3), 249-281.

Sundgren, S., and T. Svanström, (2013). Audit office size, audit quality and audit pricing: Evidence from small- and medium-sized enterprises. Accounting and Business Research. 43(1): 31-55

Wagner, E. (2011). Lower discretionary accruals in second tier clients Post-SOX: Client quality or auditor quality? $\mathrm{Ph}$. D. Dissertation. The City University of New York

Wang, B., Qingquan Xin. (2011). Auditor choice and accruals patterns of cross-listed firms. China Journal of Accounting Research. 4: 233-251.

Wooldridge, J. M. (2010). Econometric analysis of cross section and panel data. $2^{\text {nd }}$ edition, MIT press, London, UK.

Yaşar, A. (2013). Big four auditors' audit quality and earnings management: Evidence from Turkish stock market. International Journal of Business and Social Science. 4(17):153-163.

Yasser,S. and Soliman, M. 2018. The effect of Audit Quality on Earnings Management in Developing Countries: The Case of Egypt. International Research Journal of Applied Finance. IX(4): 216-231.

Zmijewski, M. E. 1984. Methodological issues related to the estimation of financial distress prediction models. Journal of Accounting Research (Supplement): 59-82. 
Table 1: Variable definitions

\begin{tabular}{|c|c|}
\hline Variable & Definition \\
\hline Audit quality & $\begin{array}{l}\text { Audit quality measured by Abnormal Accruals } \mid \text { ABACC } \mid \text { computed from the } \\
\text { modified-Jones model (Dechow et al., 1995; Kothari et al., 2005) }\end{array}$ \\
\hline Auditor type & $\begin{array}{l}\text { - BIG is a dummy variable equal to } 1 \text { if a Big } 4 \text { audit firm exists, and } 0 \\
\text { otherwise. } \\
\text { - Foreign is a dummy variable equal to } 1 \text { if any of the Egyptian audit firms } \\
\text { that affiliate with a foreign audit firm exist, and } 0 \text { otherwise. } \\
\text { - Second is a dummy variable equal to } 1 \text { if any of the Egyptian audit firms } \\
\text { that affiliate with a foreign audit firm on second-tier exist, and } 0 \text { otherwise. } \\
\text { - Third is a dummy variable equal to } 1 \text { if any of the Egyptian audit firms that } \\
\text { affiliate with a foreign audit on third-tier exist, and } 0 \text { otherwise. } \\
\text { - FnotBIG is a dummy variable equal to } 1 \text { if any of the Egyptian audit firms } \\
\text { that affiliate with a foreign audit firm other than big } 4 \text { exist, and } 0 \text { otherwise. } \\
\text { - Local is a dummy variable equal to } 1 \text { if any of the local audit firms that exist, } \\
\text { and } 0 \text { otherwise. } \\
\text { - ASA is a dummy variable equal to } 1 \text { if the Accountability State Authority } \\
\text { exist, and } 0 \text { otherwise }\end{array}$ \\
\hline ZIM & Financial stress score, calculated from Zmijewski's (1984) model \\
\hline Leverage & Total liabilities divided by total assets \\
\hline Return & Net income / Total Assets \\
\hline Loss & 1 to 1 if earning \\
\hline Current & ivided by current liabilities \\
\hline FSIZE & $\mathrm{m}$ of total assets \\
\hline Inherent & ( Accounts receivables + Inventory) / Total Assets \\
\hline OFLow & Operating cash flows / Total assets in the prior year \\
\hline LnAge & Natural logarithm of Company age \\
\hline Complex & Sales / Total assets in the prior year \\
\hline
\end{tabular}


Table 2: Descriptive Statistics

\begin{tabular}{lcrrrr}
\hline & $\mathrm{n}$ & Mean & STD & Min & Max \\
\hline ABACC & 602 & 0.08 & 0.10 & 0.00 & 1.02 \\
Big & 602 & 0.22 & 0.42 & 0.00 & 1.00 \\
Foreign & 602 & 0.52 & 0.50 & 0.00 & 1.00 \\
FnotBIG & 602 & 0.30 & 0.46 & 0.00 & 1.00 \\
Second & 602 & 0.05 & 0.23 & 0.00 & 1.00 \\
Third & 602 & 0.25 & 0.43 & 0.00 & 1.00 \\
ASA & 602 & 0.15 & 0.36 & 0.00 & 1.00 \\
Local & 602 & 0.33 & 0.47 & 0.00 & 1.00 \\
FSIZE & 602 & 19.69 & 1.68 & 15.16 & 24.31 \\
Zim & 602 & 0.15 & 0.27 & 0.00 & 1.00 \\
Leverage & 602 & 0.46 & 0.33 & 0.01 & 4.03 \\
Loss & 602 & 0.21 & 0.41 & 0.00 & 1.00 \\
ROA & 602 & 0.04 & 0.10 & -0.58 & 0.92 \\
OFLow & 602 & 0.05 & 0.15 & -0.70 & 1.38 \\
Inherent & 602 & 0.44 & 0.32 & 0.00 & 3.48 \\
LnAge & 602 & 3.24 & 0.67 & 0.69 & 4.74 \\
Complex & 602 & 0.66 & 0.78 & -0.01 & 5.85 \\
\hline
\end{tabular}


Table 3: Correlation Matrix

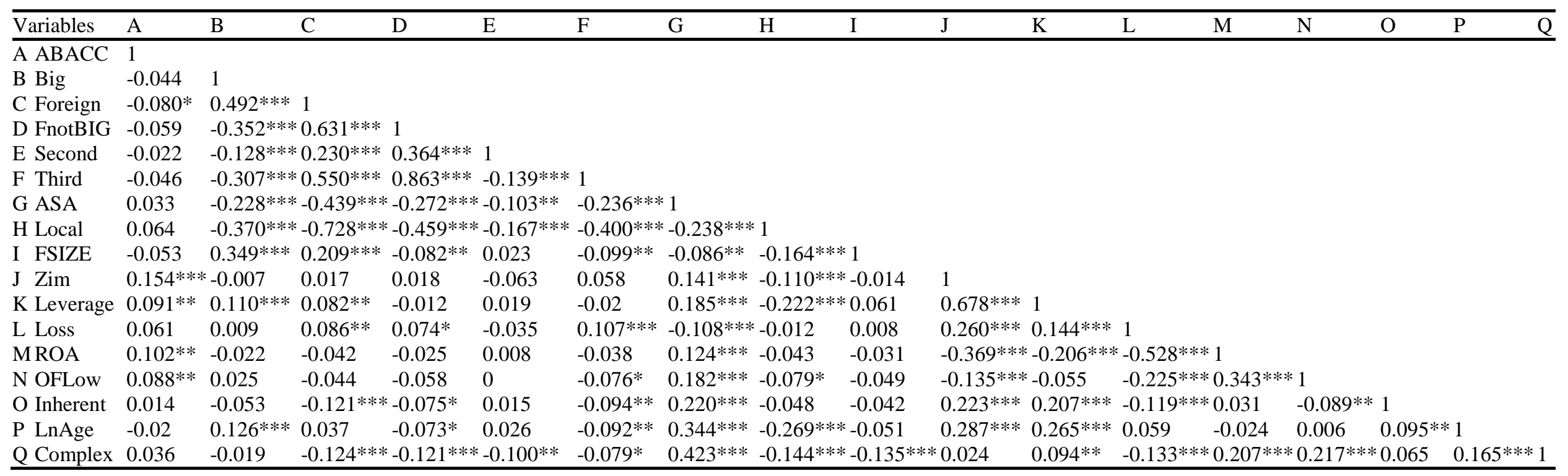

$$
* * * \mathrm{p}<0.01, * * \mathrm{p}<0.05, * \mathrm{p}<0.1
$$


Table 4: The effect of auditor type on audit quality using ABACC as a dependent variable

\begin{tabular}{|c|c|c|c|c|c|c|c|}
\hline \multirow[t]{2}{*}{ Variables } & \multicolumn{7}{|c|}{ Dependent variable: ABACC using the cross-sectional modified Jones (1991) model } \\
\hline & (1) & (2) & (3) & (4) & (5) & (6) & (7) \\
\hline \multicolumn{8}{|c|}{ Panel A: auditor type } \\
\hline Big & $\begin{array}{l}-0.003 \\
(-0.27)\end{array}$ & & & & & & \\
\hline Foreign & & $\begin{array}{l}-0.019 * * \\
(-2.10)\end{array}$ & & & & & \\
\hline ASA & & & $\begin{array}{l}0.009 \\
(0.64)\end{array}$ & & & & \\
\hline Local & & & & $\begin{array}{l}0.018^{*} \\
(1.90)\end{array}$ & & & \\
\hline FnotBIG & & & & & $\begin{array}{l}-0.019 * * \\
(-2.36)\end{array}$ & & \\
\hline Second & & & & & & $\begin{array}{l}0.004 \\
(0.27)\end{array}$ & \\
\hline Third & & & & & & & $\begin{array}{l}-0.022 * * \\
(-2.51) \\
\end{array}$ \\
\hline \multicolumn{8}{|c|}{ Panel B: Control Variables } \\
\hline FSIZE & $\begin{array}{l}-0.006 \\
(-1.25)\end{array}$ & $\begin{array}{l}-0.005 \\
(-1.13)\end{array}$ & $\begin{array}{l}-0.006 \\
(-1.47)\end{array}$ & $\begin{array}{l}-0.005 \\
(-1.16)\end{array}$ & $\begin{array}{l}-0.007^{*} \\
(-1.73)\end{array}$ & $\begin{array}{l}-0.006 \\
(-1.48)\end{array}$ & $\begin{array}{l}-0.007^{*} \\
(-1.76)\end{array}$ \\
\hline Zim & $\begin{array}{l}0.070 * * \\
(2.00)\end{array}$ & $\begin{array}{l}0.070 * * \\
(2.02)\end{array}$ & $\begin{array}{l}0.069 * * \\
(1.97)\end{array}$ & $\begin{array}{l}0.073^{* *} \\
(2.10)\end{array}$ & $\begin{array}{l}0.073 * * \\
(2.09)\end{array}$ & $\begin{array}{l}0.071 * * \\
(2.04)\end{array}$ & $\begin{array}{l}0.075 * * \\
(2.15)\end{array}$ \\
\hline Leverage & $\begin{array}{l}0.002 \\
(0.12)\end{array}$ & $\begin{array}{l}0.005 \\
(0.30)\end{array}$ & $\begin{array}{l}0.001 \\
(0.05)\end{array}$ & $\begin{array}{l}0.006 \\
(0.41)\end{array}$ & $\begin{array}{l}0.001 \\
(0.09)\end{array}$ & $\begin{array}{l}0.001 \\
(0.07)\end{array}$ & $\begin{array}{l}-0.000 \\
(-0.02)\end{array}$ \\
\hline Loss & $\begin{array}{l}0.041^{* *} \\
(2.02)\end{array}$ & $\begin{array}{l}0.043 * * \\
(2.11)\end{array}$ & $\begin{array}{l}0.042 * * \\
(2.03)\end{array}$ & $\begin{array}{l}0.042 * * \\
(2.06)\end{array}$ & $\begin{array}{l}0.042 * * \\
(2.09)\end{array}$ & $\begin{array}{l}0.041 * * \\
(2.02)\end{array}$ & $\begin{array}{l}0.043 * * \\
(2.12)\end{array}$ \\
\hline ROA & $\begin{array}{l}0.028 \\
(1.63)\end{array}$ & $\begin{array}{l}0.029^{*} \\
(1.68)\end{array}$ & $\begin{array}{l}0.027 \\
(1.63)\end{array}$ & $\begin{array}{l}0.029^{*} \\
(1.70)\end{array}$ & $\begin{array}{l}0.028^{*} \\
(1.66)\end{array}$ & $\begin{array}{l}0.028 \\
(1.62)\end{array}$ & $\begin{array}{l}0.028^{*} \\
(1.67)\end{array}$ \\
\hline OFLow & $\begin{array}{l}0.006 \\
(0.33)\end{array}$ & $\begin{array}{l}0.005 \\
(0.32)\end{array}$ & $\begin{array}{l}0.005 \\
(0.31)\end{array}$ & $\begin{array}{l}0.006 \\
(0.35)\end{array}$ & $\begin{array}{l}0.005 \\
(0.31)\end{array}$ & $\begin{array}{l}0.006 \\
(0.32)\end{array}$ & $\begin{array}{l}0.005 \\
(0.29)\end{array}$ \\
\hline Inherent & $\begin{array}{l}-0.013 \\
(-0.80)\end{array}$ & $\begin{array}{l}-0.015 \\
(-0.93)\end{array}$ & $\begin{array}{l}-0.014 \\
(-0.90)\end{array}$ & $\begin{array}{l}-0.011 \\
(-0.72)\end{array}$ & $\begin{array}{l}-0.014 \\
(-0.87)\end{array}$ & $\begin{array}{l}-0.013 \\
(-0.80)\end{array}$ & $\begin{array}{l}-0.015 \\
(-0.94)\end{array}$ \\
\hline LnAge & $\begin{array}{l}-0.010^{* *} \\
(-2.05)\end{array}$ & $\begin{array}{l}-0.010 * * \\
(-2.05)\end{array}$ & $\begin{array}{l}-0.011^{* *} \\
(-2.04)\end{array}$ & $\begin{array}{l}-0.008^{*} \\
(-1.73)\end{array}$ & $\begin{array}{l}-0.011 * * \\
(-2.20)\end{array}$ & $\begin{array}{l}-0.010 * * \\
(-2.05)\end{array}$ & $\begin{array}{l}-0.011^{* *} \\
(-2.25)\end{array}$ \\
\hline Complex & $\begin{array}{l}-0.005 \\
(-0.59)\end{array}$ & $\begin{array}{l}-0.006 \\
(-0.77)\end{array}$ & $\begin{array}{l}-0.006 \\
(-0.69)\end{array}$ & $\begin{array}{l}-0.004 \\
(-0.50)\end{array}$ & $\begin{array}{l}-0.006 \\
(-0.79)\end{array}$ & $\begin{array}{l}-0.005 \\
(-0.57)\end{array}$ & $\begin{array}{l}-0.006 \\
(-0.74)\end{array}$ \\
\hline Year & Included & Included & Included & Included & Included & Included & Included \\
\hline Industry & Included & Included & Included & Included & Included & Included & Included \\
\hline Intercept & $\begin{array}{l}0.019 \\
(1.62)\end{array}$ & $\begin{array}{l}0.020^{*} \\
(1.74)\end{array}$ & $\begin{array}{l}0.011 \\
(0.60)\end{array}$ & $\begin{array}{l}0.017 \\
(1.47)\end{array}$ & $\begin{array}{l}0.020^{*} \\
(1.68)\end{array}$ & $\begin{array}{l}0.019 \\
(1.61)\end{array}$ & $\begin{array}{l}0.020^{*} \\
(1.70)\end{array}$ \\
\hline F-value & $2.89 * * *$ & $2.99 * * *$ & $2.86^{* * *}$ & $2.97 * * *$ & $2.97 * * *$ & $2.87 * * *$ & $2.95 * * *$ \\
\hline R-squared & 0.115 & 0.122 & 0.116 & 0.120 & 0.122 & 0.115 & 0.123 \\
\hline Adj-R-squared & 0.082 & 0.088 & 0.082 & 0.087 & 0.088 & 0.082 & 0.089 \\
\hline No. of obs. & 602 & 602 & 602 & 602 & 602 & 602 & 602 \\
\hline
\end{tabular}


Table 5: The effect of auditor type on audit quality using the Kothari et al. (2005) model

\begin{tabular}{|c|c|c|c|c|c|c|c|}
\hline \multirow[t]{2}{*}{ Variables } & \multicolumn{7}{|c|}{ Dependent variable: ABACC using the Kothari et al. (2005) model } \\
\hline & (1) & (2) & (3) & (4) & (5) & (6) & (7) \\
\hline \multicolumn{8}{|c|}{ Panel A: auditor type } \\
\hline Big & $\begin{array}{l}-0.007 \\
(-0.78)\end{array}$ & & & & & & \\
\hline Foreign & & $\begin{array}{l}-0.019 * * \\
(-2.49)\end{array}$ & & & & & \\
\hline ASA & & & $\begin{array}{l}0.001 \\
(0.08)\end{array}$ & & & & \\
\hline Local & & & & $\begin{array}{l}0.024 * * * \\
(2.96)\end{array}$ & & & \\
\hline FnotBIG & & & & & $\begin{array}{l}-0.017 * * \\
(-2.50)\end{array}$ & & \\
\hline Second & & & & & & $\begin{array}{l}0.007 \\
(0.68)\end{array}$ & \\
\hline Third & & & & & & & $\begin{array}{l}-0.020 * * * \\
(-2.78)\end{array}$ \\
\hline \multicolumn{8}{|c|}{ Panel B: Control Variables } \\
\hline FSIZE & $\begin{array}{l}0.001 \\
(0.34)\end{array}$ & $\begin{array}{l}0.002 \\
(0.53)\end{array}$ & $\begin{array}{l}0.000 \\
(0.09)\end{array}$ & $\begin{array}{l}0.002 \\
(0.59)\end{array}$ & $\begin{array}{l}-0.001 \\
(-0.20)\end{array}$ & $\begin{array}{l}0.000 \\
(0.10)\end{array}$ & $\begin{array}{l}-0.001 \\
(-0.23)\end{array}$ \\
\hline Zim & $\begin{array}{l}0.022 \\
(0.85)\end{array}$ & $\begin{array}{l}0.022 \\
(0.88)\end{array}$ & $\begin{array}{l}0.022 \\
(0.89)\end{array}$ & $\begin{array}{l}0.025 \\
(1.01)\end{array}$ & $\begin{array}{l}0.024 \\
(0.97)\end{array}$ & $\begin{array}{l}0.023 \\
(0.93)\end{array}$ & $\begin{array}{l}0.027 \\
(1.06)\end{array}$ \\
\hline Leverage & $\begin{array}{l}-0.001 \\
(-0.08)\end{array}$ & $\begin{array}{l}0.001 \\
(0.15)\end{array}$ & $\begin{array}{l}-0.002 \\
(-0.21)\end{array}$ & $\begin{array}{l}0.004 \\
(0.44)\end{array}$ & $\begin{array}{l}-0.002 \\
(-0.22)\end{array}$ & $\begin{array}{l}-0.002 \\
(-0.27)\end{array}$ & $\begin{array}{l}-0.003 \\
(-0.37)\end{array}$ \\
\hline Loss & $\begin{array}{l}0.004 \\
(0.35)\end{array}$ & $\begin{array}{l}0.005 \\
(0.53)\end{array}$ & $\begin{array}{l}0.003 \\
(0.34)\end{array}$ & $\begin{array}{l}0.005 \\
(0.46)\end{array}$ & $\begin{array}{l}0.005 \\
(0.46)\end{array}$ & $\begin{array}{l}0.004 \\
(0.35)\end{array}$ & $\begin{array}{l}0.005 \\
(0.54)\end{array}$ \\
\hline ROA & $\begin{array}{l}0.003 \\
(0.79)\end{array}$ & $\begin{array}{l}0.004 \\
(1.00)\end{array}$ & $\begin{array}{l}0.003 \\
(0.76)\end{array}$ & $\begin{array}{l}0.005 \\
(1.14)\end{array}$ & $\begin{array}{l}0.004 \\
(0.90)\end{array}$ & $\begin{array}{l}0.003 \\
(0.75)\end{array}$ & $\begin{array}{l}0.004 \\
(0.91)\end{array}$ \\
\hline OFLow & $\begin{array}{l}0.015 \\
(1.02)\end{array}$ & $\begin{array}{l}0.015 \\
(1.01)\end{array}$ & $\begin{array}{l}0.015 \\
(1.02)\end{array}$ & $\begin{array}{l}0.016 \\
(1.06)\end{array}$ & $\begin{array}{l}0.015 \\
(1.00)\end{array}$ & $\begin{array}{l}0.015 \\
(1.01)\end{array}$ & $\begin{array}{l}0.014 \\
(0.98)\end{array}$ \\
\hline Inherent & $\begin{array}{l}-0.006 \\
(-0.55)\end{array}$ & $\begin{array}{l}-0.008 \\
(-0.73)\end{array}$ & $\begin{array}{l}-0.006 \\
(-0.56)\end{array}$ & $\begin{array}{l}-0.004 \\
(-0.39)\end{array}$ & $\begin{array}{l}-0.007 \\
(-0.63)\end{array}$ & $\begin{array}{l}-0.006 \\
(-0.56)\end{array}$ & $\begin{array}{l}-0.008 \\
(-0.74)\end{array}$ \\
\hline LnAge & $\begin{array}{l}-0.005 \\
(-1.43)\end{array}$ & $\begin{array}{l}-0.005 \\
(-1.51)\end{array}$ & $\begin{array}{l}-0.006 \\
(-1.42)\end{array}$ & $\begin{array}{l}-0.003 \\
(-0.95)\end{array}$ & $\begin{array}{l}-0.006^{*} \\
(-1.67)\end{array}$ & $\begin{array}{l}-0.006 \\
(-1.53)\end{array}$ & $\begin{array}{l}-0.007 * \\
(-1.74)\end{array}$ \\
\hline Complex & $\begin{array}{l}0.003 \\
(0.53)\end{array}$ & $\begin{array}{l}0.001 \\
(0.25)\end{array}$ & $\begin{array}{l}0.003 \\
(0.45)\end{array}$ & $\begin{array}{l}0.004 \\
(0.69)\end{array}$ & $\begin{array}{l}0.001 \\
(0.26)\end{array}$ & $\begin{array}{l}0.003 \\
(0.56)\end{array}$ & $\begin{array}{l}0.002 \\
(0.33)\end{array}$ \\
\hline Year & Included & Included & Included & Included & Included & Included & Included \\
\hline Industry & Included & Included & Included & Included & Included & Included & Included \\
\hline Intercept & $\begin{array}{l}0.024 * * * \\
(3.72)\end{array}$ & $\begin{array}{l}0.025 * * * \\
(3.86)\end{array}$ & $\begin{array}{l}0.023 * \\
(1.77)\end{array}$ & $\begin{array}{l}0.021 * * * \\
(3.40)\end{array}$ & $\begin{array}{l}0.024 * * * \\
(3.78)\end{array}$ & $\begin{array}{l}0.024 * * * \\
(3.70)\end{array}$ & $\begin{array}{l}0.025 * * * \\
(3.82)\end{array}$ \\
\hline F-value & $2.76^{* * *}$ & $3.01 * * *$ & $2.66^{* * *}$ & 3.06 & $2.88 * * *$ & $2.67 * * *$ & $2.97 * * *$ \\
\hline R-squared & 0.090 & 0.100 & 0.089 & 0.103 & 0.097 & 0.090 & 0.099 \\
\hline $\operatorname{Adj}-R^{2}$ & 0.056 & 0.065 & 0.055 & 0.068 & 0.063 & 0.055 & 0.065 \\
\hline No. of obs. & 602 & 602 & 602 & 602 & 602 & 602 & 602 \\
\hline
\end{tabular}


Table 6: The effect of auditor type on audit quality using fixed-effect regression

\begin{tabular}{|c|c|c|c|c|c|c|c|}
\hline \multirow[t]{2}{*}{ Variables } & \multicolumn{7}{|c|}{ Dependent variable: ABACC using the cross-sectional modified Jones (1991) model } \\
\hline & (1) & (2) & (3) & (4) & (5) & (6) & (7) \\
\hline \multicolumn{8}{|c|}{ Panel A: auditor type } \\
\hline Big & $\begin{array}{l}-0.003 \\
(-0.32)\end{array}$ & & & & & & \\
\hline Foreign & & $\begin{array}{l}-0.017 * * \\
(-2.04)\end{array}$ & & & & & \\
\hline ASA & & & $\begin{array}{l}0.005 \\
(0.37)\end{array}$ & & & & \\
\hline Local & & & & $\begin{array}{l}0.020 * * \\
(2.09)\end{array}$ & & & \\
\hline FnotBIG & & & & & $\begin{array}{l}-0.020 * * \\
(-2.15)\end{array}$ & & \\
\hline Second & & & & & & $\begin{array}{l}-0.000 \\
(-0.01)\end{array}$ & \\
\hline Third & & & & & & & $\begin{array}{l}-0.021 * * \\
(-2.17) \\
\end{array}$ \\
\hline \multicolumn{8}{|c|}{ Panel B: Control Variables } \\
\hline FSIZE & $\begin{array}{l}-0.007 \\
(-1.50)\end{array}$ & $\begin{array}{l}-0.006 \\
(-1.33)\end{array}$ & $\begin{array}{l}-0.008^{*} \\
(-1.69)\end{array}$ & $\begin{array}{l}-0.006 \\
(-1.35)\end{array}$ & $\begin{array}{l}-0.009 * \\
(-1.94)\end{array}$ & $\begin{array}{l}-0.008^{*} \\
(-1.70)\end{array}$ & $\begin{array}{l}-0.009^{*} \\
(-1.96)\end{array}$ \\
\hline Zim & $\begin{array}{l}0.087 \text { *** } \\
(3.85)\end{array}$ & $\begin{array}{l}0.086^{* * * *} \\
(3.83)\end{array}$ & $\begin{array}{l}0.087 \text { *** } \\
(3.86)\end{array}$ & $\begin{array}{l}0.087 \text { *** } \\
(3.87)\end{array}$ & $\begin{array}{l}0.089 * * * \\
(3.96)\end{array}$ & $\begin{array}{l}0.088^{* * * *} \\
(3.87)\end{array}$ & $\begin{array}{l}0.092 * * * \\
(4.07)\end{array}$ \\
\hline Leverage & $\begin{array}{l}-0.005 \\
(-0.28)\end{array}$ & $\begin{array}{l}-0.002 \\
(-0.12)\end{array}$ & $\begin{array}{l}-0.006 \\
(-0.34)\end{array}$ & $\begin{array}{l}0.000 \\
(0.00)\end{array}$ & $\begin{array}{l}-0.005 \\
(-0.31)\end{array}$ & $\begin{array}{l}-0.006 \\
(-0.32)\end{array}$ & $\begin{array}{l}-0.007 \\
(-0.42)\end{array}$ \\
\hline Loss & $\begin{array}{l}0.039 * * * \\
(3.25)\end{array}$ & $\begin{array}{l}0.041 * * * \\
(3.38)\end{array}$ & $\begin{array}{l}0.039 * * * \\
(3.27)\end{array}$ & $\begin{array}{l}0.040 * * * \\
(3.35)\end{array}$ & $\begin{array}{l}0.041 * * * \\
(3.39)\end{array}$ & $\begin{array}{l}0.039 * * * \\
(3.25)\end{array}$ & $\begin{array}{l}0.041 * * * \\
(3.44)\end{array}$ \\
\hline ROA & $\begin{array}{l}0.029 * * * \\
(5.34)\end{array}$ & $\begin{array}{l}0.030 * * * \\
(5.42)\end{array}$ & $\begin{array}{l}0.029 * * * \\
(5.30)\end{array}$ & $\begin{array}{l}0.030 \text { *** } \\
(5.52)\end{array}$ & $\begin{array}{l}0.030 * * * \\
(5.44)\end{array}$ & $\begin{array}{l}0.029 * * * \\
(5.34)\end{array}$ & $\begin{array}{l}0.030 * * * \\
(5.46)\end{array}$ \\
\hline OFLow & $\begin{array}{l}0.006 \\
(1.48)\end{array}$ & $\begin{array}{l}0.006 \\
(1.43)\end{array}$ & $\begin{array}{l}0.006 \\
(1.41)\end{array}$ & $\begin{array}{l}0.007 \\
(1.61)\end{array}$ & $\begin{array}{l}0.006 \\
(1.39)\end{array}$ & $\begin{array}{l}0.006 \\
(1.47)\end{array}$ & $\begin{array}{l}0.006 \\
(1.34)\end{array}$ \\
\hline Inherent & $\begin{array}{l}-0.004 \\
(-0.33)\end{array}$ & $\begin{array}{l}-0.008 \\
(-0.55)\end{array}$ & $\begin{array}{l}-0.005 \\
(-0.37)\end{array}$ & $\begin{array}{l}-0.004 \\
(-0.28)\end{array}$ & $\begin{array}{l}-0.006 \\
(-0.46)\end{array}$ & $\begin{array}{l}-0.004 \\
(-0.31)\end{array}$ & $\begin{array}{l}-0.007 \\
(-0.52)\end{array}$ \\
\hline LnAge & $\begin{array}{l}-0.009 * * \\
(-2.22)\end{array}$ & $\begin{array}{l}-0.009 * * \\
(-2.19)\end{array}$ & $\begin{array}{l}-0.010 * * \\
(-2.31)\end{array}$ & $\begin{array}{l}-0.008^{*} \\
(-1.77)\end{array}$ & $\begin{array}{l}-0.010 * * \\
(-2.45)\end{array}$ & $\begin{array}{l}-0.010 * * \\
(-2.29)\end{array}$ & $\begin{array}{l}-0.011 * * \\
(-2.53)\end{array}$ \\
\hline Complex & $\begin{array}{l}-0.002 \\
(-0.29)\end{array}$ & $\begin{array}{l}-0.003 \\
(-0.51)\end{array}$ & $\begin{array}{l}-0.002 \\
(-0.40)\end{array}$ & $\begin{array}{l}-0.001 \\
(-0.10)\end{array}$ & $\begin{array}{l}-0.003 \\
(-0.54)\end{array}$ & $\begin{array}{l}-0.002 \\
(-0.29)\end{array}$ & $\begin{array}{l}-0.002 \\
(-0.43)\end{array}$ \\
\hline Year & Included & Included & Included & Included & Included & Included & Included \\
\hline Firm & Included & Included & Included & Included & Included & Included & Included \\
\hline Intercept & $\begin{array}{l}0.063^{* * * *} \\
(6.28)\end{array}$ & $\begin{array}{l}0.072 * * * \\
(6.62)\end{array}$ & $\begin{array}{l}0.063 * * * \\
(6.35)\end{array}$ & $\begin{array}{l}0.053^{* * *} * \\
(4.80)\end{array}$ & $\begin{array}{l}0.070 * * * \\
(6.72)\end{array}$ & $\begin{array}{l}0.063^{* * * *} \\
(6.31)\end{array}$ & $\begin{array}{l}0.069 * * * \\
(6.73)\end{array}$ \\
\hline R-squared & 0.090 & 0.100 & 0.089 & 0.103 & 0.097 & 0.090 & 0.099 \\
\hline Adj- $R^{2}$ & 0.056 & 0.065 & 0.055 & 0.068 & 0.063 & 0.055 & 0.065 \\
\hline No. of obs. & 602 & 602 & 602 & 602 & 602 & 602 & 602 \\
\hline
\end{tabular}

